\title{
Dynorphin Increases Extracellular Levels of Excitatory Amino Acids in the Brain through a Non-opioid Mechanism
}

\author{
Alan I. Faden \\ Departments of Neurology and Pharmacology, Georgetown University School of Medicine, Washington, D.C. 20007
}

\begin{abstract}
Administration of dynorphin A-(1-17) (Dyn 1-17), through a microdialysis probe stereotaxically placed into rat hippocampus, caused marked increases in the extracellular levels of glutamate and aspartate. The degree and duration of elevation of these excitatory amino acids (EAA) induced by Dyn 1-17 were dose dependent but were not modified by the centrally active opioid receptor antagonist nalmefene. At comparable doses, Dyn 2-17, which is inactive at the opioid receptor, produced similar alterations in EAA as Dyn 1-17, whereas Dyn 1-8 caused significantly smaller changes of glutamate. Dynorphin and EAAs have each been implicated as pathophysiological factors in brain or spinal cord injuries, with dynorphin's actions shown to involve both opioid and non-opioid components. The present observations indicate a direct potential linkage between dynorphin and excitotoxin mechanisms of CNS injury and provide further support for the concept that dynorphin's pathophysiologic effects may include non-opioid actions of this peptide.
\end{abstract}

Dynorphin A-(1-17) (Dyn 1-17) is an cndogenous opioid peptide that has been implicated in the pathophysiology of both traumatic brain injury (TBI) and spinal cord injury (SCI). Following SCI, dynorphin-like immunoreactive material accumulates at the trauma site in direct proportion to injury severity, whereas other endogenous opioids including methionine-enkephalin, leucine-enkephalin, or $\beta$-endorphin are unchanged (Faden et al., 1985). Levels of dynorphin, but not those of other endogenous opioids, are also increased following TBI at sites showing the most severe neuropathological changes (McIntosh et al., 1987). Administration of antiserum to dynorphin, but not antiserum to leucine-enkephalin, reduces posttraumatic neurological dysfunction after SCI (Faden, 1990); in contrast, central administration of dynorphin exacerbates the consequences of TBI or SCI (McIntosh et al., 1988; Faden, 1990). Consistent with its proposed pathophysiological role, intrathecal dynorphin administration causcs biochemical changes within the spinal cord, diminished blood flow (Long et al., 1987), motor deficits

\footnotetext{
Received July 11, 1991; revised Sept. 11, 1991; accepted Sept. 18, 1991.

This work was supported by grants from the National Institutes of Health (SR01NS27849-02) and the Centers for Disease Control (R49/CCR903623). I thank Charles Buhs, Peter Halt, and Florence Chang for technical assistance, and Patricia Doyle for help in preparation of the manuscript. We adhered to the principles enumerated in the Guide for the Care and Use of Laboratory Animals, prepared by the Committee on Care and Use of Laboratory Animals of the Institute of Laboratory Resources, National Research Council [DHEW Pub. No. (NIH) 85-23, 1985].

Correspondence should be addressed to Alan I. Faden, M.D., Office of the Dean of Research, Medical-Dental Building, N.W. 101, Georgetown University Medical Center, 3900 Reservoir Road, N.W., Washington, DC 20007.

Copyright (c) 1992 Society for Neuroscience $0270-6474 / 92 / 120425-05 \$ 05.00 / 0$
}

(Faden and Jacobs, 1984; Herman and Goldstein, 1985; Long et al., 1988), and histological damage that simulate the consequences of spinal cord trauma (for review, see Bakshi et al., 1990).

Excitatory amino acids (EAA) have also been implicated as pathophysiological factors in SCI and TBI through actions mediated by NMDA receptors. Extracellular levels of glutamate and aspartate increase markedly after CNS trauma (Faden et al., 1989; Katayama et al., 1989; Nilsson et al., 1990; Panter et al., 1990) in proportion to injury severity; tissue levels of these EAA are also modified in response to trauma (Demediuk et al., 1989). NMDA, but not its enantiomer NMLA, worsens neurological dysfunction following SCI (Faden and Simon, 1988). Treatment with NMDA antagonists, including both competitive and noncompetitive blockers, limits behavioral deficits, biochemical and metabolic alterations, and anatomical changes after TBI (Hayes et al., 1988; Faden et al., 1989; McIntosh et al., 1989; Shapira et al., 1990) or SCI (Faden and Simon, 1988; Gomez-Pinilla et al., 1989; Faden et al., 1990).

That dynorphin- and excitotoxin-induced physiological changes may be linked was first suggested by Caudle and Isaac (1988). This concept was supported and extended by others. Intrathecal dynorphin administration was shown to cause depletion of tissue levels of glutamate and aspartate (Bakshi et al., 1990). Moreover, NMDA antagonists (including competitive, noncompetitive, or glycine site antagonists) were found to limit dynorphin-induced behavioral changes and mortality (Long et al., 1989; Bakshi and Faden, 1990a,b).

The pathophysiological actions of dynorphin appear to be mediated by both opioid and non-opioid mechanisms (Faden, 1990). Des-tyrosine-dynorphin (Dyn 2-17) is inactive at opioid receptors (Walker et al., 1982) yet simulates many of the pathophysiological consequences of Dyn 1-17. NMDA antagonists reduce neurological dysfunction after either Dyn 1-17 or Dyn 2-17 (Long et al., 1989; Bakshi and Faden, 1990a,b). From such observations, it seems possible that dynorphin causes tissue damage, in part, through non-opioid mechanisms that include the release of EAA. To address this issue, microdialysis techniques have been used to determine whether dynorphin alters extracellular levels of glutamate or aspartate within the brain and whether such actions are opioid receptor mediated.

\section{Materials and Methods}

Male Sprague-Dawley rats $(400 \pm 25 \mathrm{gm})$ were anesthetized with sodium pentobarbital $(70 \mathrm{mg} / \mathrm{kg}$ body weight, i.p.). A microdialysis probe was implanted stereotaxically into hippocampus, as previously described for brain trauma studies (Faden et al., 1989). This site, which includes the CA2 and CA3 areas, shows delayed cell loss (Cortez et al., 1989), as well as the release of EAA (Faden et al., 1989) after fluid 
percussion-induced trauma. It also contains dynorphin-immunoreactive fibers (Watson et al., 1982) and NMDA receptors (Greenamyre et al., 1984). Perfusions were made with a CMA/100 microinjection pump (Carnegie Medicin AB); the probe (Bioanalytical Systems) had an outside diameter of $0.5 \mathrm{~mm}$ and a molecular mass exclusion limit of approximately $20 \mathrm{kDa}$. Probes were tested before and following microdialysis against standard solutions of amino acids. Fifty minutes after probe placement, microdialysis was begun, using artificial cerebrospinal fluid as the perfusate with a flow rate of $2 \mu \mathrm{l} / \mathrm{min}$. Samples, representing $10 \mathrm{~min}$ intervals, were analyzed for amino acids using high-performance liquid chromatography as previously described (Demediuk et al., 1989; Faden et al., 1989). Following two baseline measurements $(20 \mathrm{~min})$, dynorphin was infused beginning at $t=0 \mathrm{~min}$ through the microdialysis probe over $10 \mathrm{~min}$ at a rate of $2 \mu \mathrm{l} / \mathrm{min}$; a preliminary experiment from our laboratory using ${ }^{3} \mathrm{H}$-dynorphin $\mathrm{A}-(1-17)$ showed that approximately $5 \%$ of the administered dynorphin was delivered to the brain, consistent with a previous report (Kendrick, 1989). Groups included animals treated with Dyn $1-17$ at doses of $10 \mathrm{nmol}(n=8), 30 \mathrm{nmol}(n=13)$, and $100 \mathrm{nmol}(n=9)$; Dyn 2-17 at a dose of $30 \mathrm{nmol}(n=11)$; Dyn 1-8 at a dose of $30 \mathrm{nmol}(n=8)$; and nalmefene $(100 \mu \mathrm{g})$ plus Dyn 1-17 at a dose of $100 \mathrm{nmol}(n=10)$. For the latter experiment, nalmefene was administered at a rate of $2 \mu \mathrm{l} / \mathrm{min}$ in artificial cerebrospinal fluid over $10 \mathrm{~min}$, beginning at $t=-30 \mathrm{~min}$; as for the other experiments, dynorphin was administered beginning at $t=0 \mathrm{~min}$ over a $10 \mathrm{~min}$ period at a rate of $2 \mu \mathrm{l} / \mathrm{min}$. Following the final microdialysis collection $(t=$ $60 \mathrm{~min}$ ), animals were killed through an intraperitoneal injection of $\mathrm{T}-61(1 \mathrm{ml})$.

\section{Results}

Administration of Dyn 1-17 caused significant increases in extracellular levels of glutamate and asparate, which were related to dynorphin dose (Fig. 1). Peak changes occurred at $20 \mathrm{~min}$ with maximal increases of $1340 \%$ for glutamate and $544 \%$ for aspartate at the highest dynorphin dose. Effects on other transmitter and nontransmitter amino acids are shown in Table 1: glycine, GABA, serine, and taurine were also increased by Dyn $1-17$, although none showed a significant dose-dependent relationship. Among these amino acids, glycine and serine may modulate NMDA receptor activity (Benavides et al., 1988; Snell et al., 1988; Thomson, 1989). The alterations of the amino acids observed are qualitatively similar to those found after fluid percussion-induced TBI (Faden et al., 1989), impact-induced traumatic SCI (Panter et al., 1990), or hypoxia-ischemia of brain (Hagberg et al., 1987).

Two cxpcriments were conducted to determine whether the dynorphin-induced increase of amino acids was opioid receptor

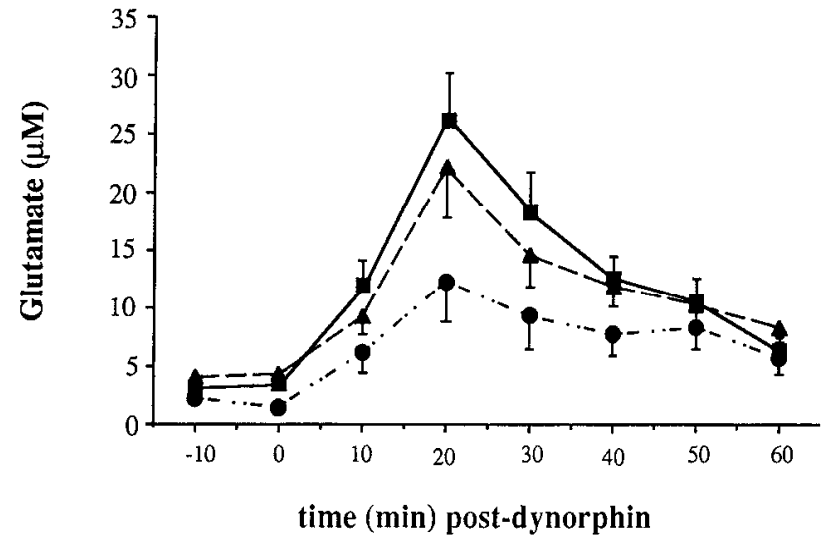

$$
\begin{aligned}
& -1 \text { DynA (1-17) } 100 \mathrm{rm} \\
& --- \text { DynA (1-17) } 30 \mathrm{~nm} \\
& --D \text { DynA (1-17) } 10 \mathrm{~mm}
\end{aligned}
$$

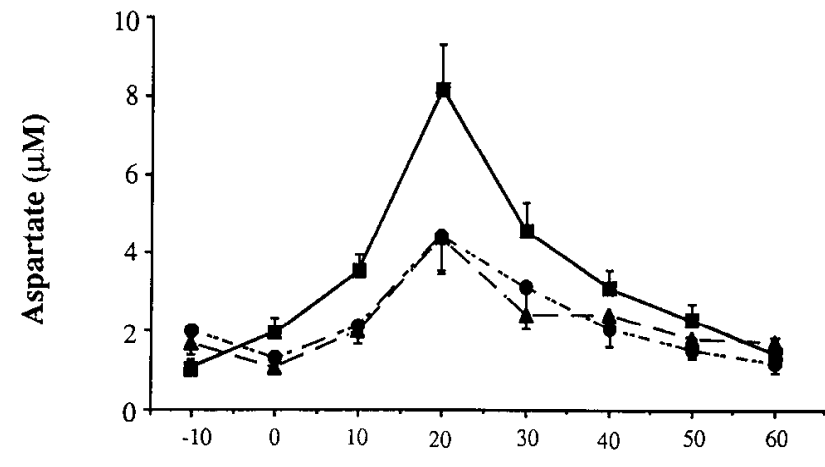

time (min) post-dynorphin

Figure 1. Changes in extracellular levels of the EAA glutamate and aspartate before and following administration of Dyn 1-17 through a microdialysis probe placed in rat hippocampus. Average values and SE are plotted as a function of time of dynorphin injection, expressed as the concentration of amino acid in the dialysate. Dynorphin administration at each dose caused significant increases in glutamate and aspartate at $20 \mathrm{~min}$ (peak elevation) as comparcd to their respective baseline (pretreatment) values (see Table 1). Increases were significantly dose related: glutamate, $r=0.38, p=0.04$; aspartate, $r=0.41, p=0.03$, using regression ANOVA.

Table 1. Maximum percentage change of amino acids after dynorphin administration

\begin{tabular}{|c|c|c|c|c|c|c|}
\hline & \multicolumn{3}{|l|}{ Dyn 1-17 } & \multirow{2}{*}{$\begin{array}{l}\text { Dyn 1-8 } \\
30 \mathrm{nmol}\end{array}$} & \multirow{2}{*}{$\begin{array}{l}\text { Dyn 2-17 } \\
30 \mathrm{nmol}\end{array}$} & \multirow{2}{*}{$\begin{array}{l}\text { Dyn } 1-17 \\
100 \mathrm{nmol} \\
+ \\
\text { nalmefene } \\
0.1 \mathrm{mg}\end{array}$} \\
\hline & $10 \mathrm{nmol}$ & $30 \mathrm{nmol}$ & $100 \mathrm{nmol}$ & & & \\
\hline Alanine & $150^{*}$ & $138^{*}$ & 140 & 208 & 124 & 109 \\
\hline Aspartate & $303^{* *}$ & $491^{* *}$ & $544^{* * *}$ & 289 & $431^{* *}$ & $678^{* * *}$ \\
\hline GABA & $396^{*}$ & $222^{* *}$ & 210 & 110 & 165 & 212 \\
\hline Glutamate & $667^{*}$ & $627^{* * * *}$ & $1340^{* * * * *}$ & $245^{*}$ & 362 & $1337^{* * *}$ \\
\hline Glutamine & 112 & 114 & 114 & 99 & 98 & 122 \\
\hline Glycine & $168^{*}$ & $242^{* *}$ & $173^{*}$ & 247 & 182 & $161^{* *}$ \\
\hline Serine & $151^{*}$ & $143^{*}$ & 130 & 87 & 139 & 126 \\
\hline Taurine & $301^{*}$ & $215^{* *}$ & $368^{* * *}$ & 111 & $151^{* *}$ & $362^{* *}$ \\
\hline Threonine & 148 & 142 & 105 & 174 & 109 & 111 \\
\hline
\end{tabular}

Data are expressed as maximal percentage changes to complement the data in Figures 1-3. For statistical purposes, however, changes are compared for each amino acid using actual (not percentage) changes from its own baseline value.

*, Significantly different from own baseline, $p<0.05 ;{ }^{* *}, p<0.01$; ***, $p<0.001$ ( $t$ test). 

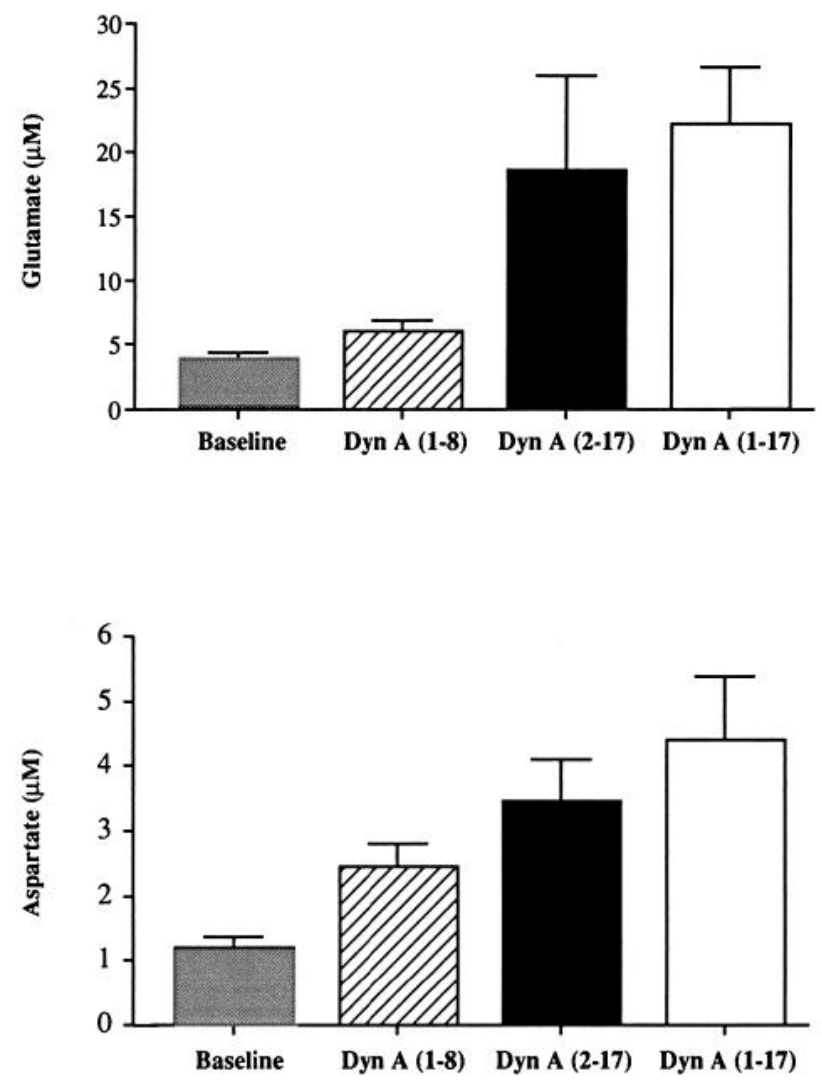

Figure 2. Comparison of peak levels $( \pm \mathrm{SE})$ of extracellular glutamate and aspartate following administration of equal concentrations $(30 \mathrm{nmol})$ of Dyn 1-17, Dyn 2-17, or Dyn 1-8 versus baseline values. Changes induced by Dyn 1-17 and Dyn 2-17 are statistically indistinguishable, whether the data are examined in terms of absolute values as shown here or as percentage change from baseline (see Table 1). Alterations in glutamate, but not aspartate, after administration of Dyn 1-17 were significantly higher than following Dyn 1-8 ( $t$ test with Bonferroni correction, $p<0.05$ ). Baseline values were similar across the groups and have been averaged here.

mediated. Dyn 2-17, which does not act at opioid receptors but is physiologically active (Walker et al., 1982), produced elevations in glutamate and aspartate that were statistically indistinguishable from those of Dyn 1-17 at similar doses (Fig. 2). Consistent with this observation, administration of a relatively high dose of the opioid receptor antagonist nalmefene (Bakshi et al., 1990) failed to modify the effects of Dyn 1-17 on EAA release (Fig. 3). Nalmefene, by itself, did not alter the basal levels of glutamate or aspartate.

To examine further the structure-activity relationship for dynorphin with regard to EAA changes, other animals received Dyn 1-8; this peptide, unlike Dyn 1-17, Dyn 2-17, Dyn 1-13, or Dyn 3-13, does not cause paralysis after intrathecal administration in rats (Przewlocki et al., 1983; Faden and Jacobs, 1984; Stevens and Yaksh, 1986). Alterations in extracellular levels of glutamate or aspartate after Dyn 1-8 were modest and were significantly less than those of Dyn 1-17 (Fig. 2).

\section{Discussion}

Increasing evidence supports the concept that dynorphin-induced and excitotoxin-induced tissue injury may be closely linked. Intrathecal administration of dynorphin to rats, at doses that produce behavioral and histological changes, cause changes
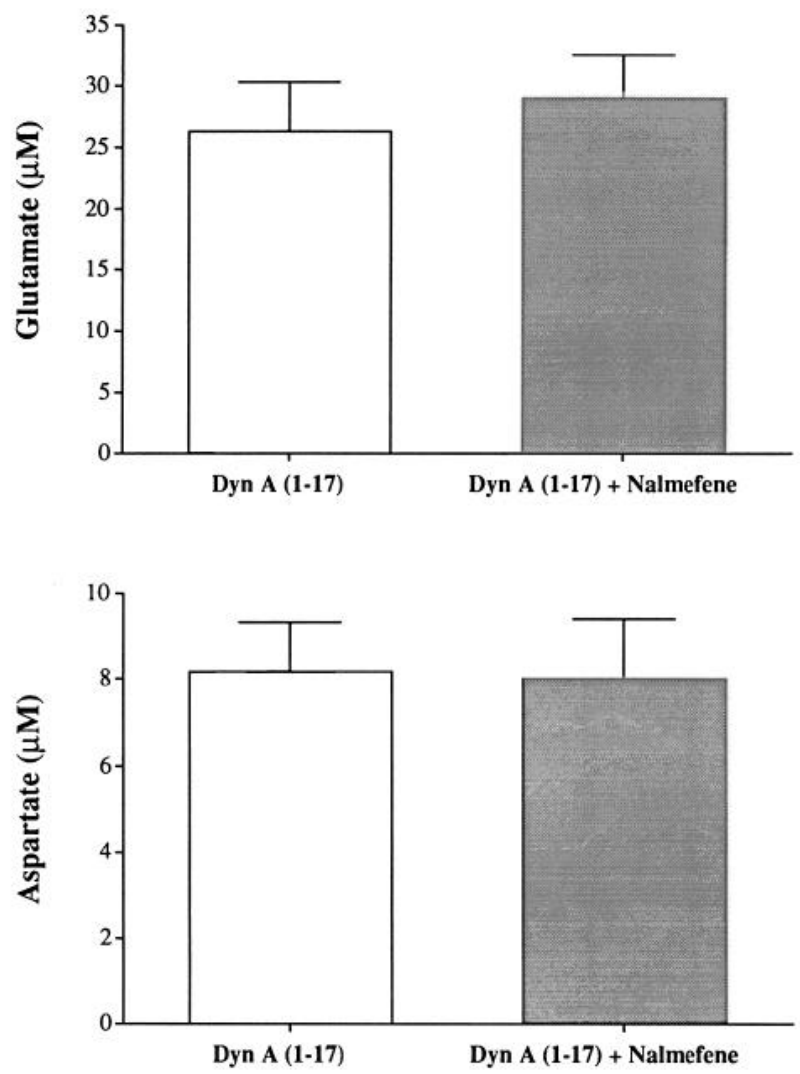

Figure 3. Comparison of peak levels $( \pm$ SE) of extracellular glutamate and aspartate following administration of $100 \mathrm{nmol}$ Dyn 1-17, with or without the opioid receptor antagonist nalmefene. Effect of dynorphin on these EAA was not significantly modified by treatment with nalmefene, whether the data are expressed in terms of absolute values as shown here or as percentage change from baseline as shown in Table 1.

in the tissue levels of glutamate and aspartate (Bakshi et al., 1990). A variety of structurally different NMDA antagonists, with differing mechanisms of action, reduce neurological and histological abnormalities produced by dynorphin (Long et al., 1989; Bakshi and Faden, 1990a,b). Consistent with these findings, the present data show that administration of dynorphin through a microdialysis probe placed in rat hippocampus causes a dose-related increase in the extracellular levels of glutamate and aspartate.

Dynorphin-induced SCI appears to be mediated, in part, through non-opioid mechanisms; Dyn 2-17 and Dyn 3-13, which are believed to be inactive at opioid receptors, cause changes in blood flow or motor function that are not modified by opioid receptor antagonists (Faden and Jacobs, 1984; Long et al., 1987, 1988; Faden, 1990). The present findings show that Dyn 1-17 and Dyn 2-17 cause indistinguishable increases of EAA, which are not modified by a centrally active opioid receptor antagonist, supporting a non-opioid mechanism of action. These observations are consistent with a growing body of evidence that dynorphin may have substantial physiological or pathophysiological actions that are not mediated by opioid receptors (Walker et al., 1982; Faden and Jacobs, 1984; Long et al., 1987, 1988; Faden, 1990).

There have been many reported relationships among opioids, opioid receptors, and EAA. Such relationships are complicated and may differ across various experimental models. Receptor 
binding studies using Dyn 1-13 demonstrated a direct interaction of this peptide with the NMDA receptor, where it may serve as an antagonist (Massardier and Hunt, 1989). In support of this observation, high doses of dynorphin protected against NMDA-induced toxicity to cortical neurons ini culture (Choi et al., 1989). Other opioids, as well as their non-opioid enantiomers, also selectively attenuated NMDA neurotoxicity in the same cortical cell culture system, with the non-opioid dextroisomers being most active (Choi and Viseskul, 1988). However, in hippocampal slice a variety of opioid agonists have been shown to increase synaptic excitability of dentate granule cells or CA1 pyramidal cells; dynorphin enhanced the excitability of the dentate granule cells, an action that was relatively insensitive to naloxone (Neumaier et al., 1988). Moreover, a noncompetitive NMDA antagonist was found to inhibit morphine tolerance and dependence (Trujillo and Akil, 1991). Glutamate and dynorphins can each be released from hippocampal mossy fiber synaptosomes (Terrian et al., 1988), with both dynorphin-immunoreactive fibers and glutamate-binding sites found in the same hippocampal regions (Watson et al., 1982; Greenamyre et al., 1984). In contrast to the results of the present study and some of the reports mentioned above, in other model systems the effects of endogenous opioids on EAA release appear to be mediated, at least in part, by opioid receptors. Thus, opioid receptor antagonists stereospecifically reduce the release of EAA following global cerebral ischemia and reperfusion (Graham et al., 1990b) and attenuate alterations of EAA after intrathecal dynorphin (Bakshi et al., 1990).

The mechanism by which dynorphin may increase EAA is speculative. One possibility is that dynorphin reduces local tissue blood flow sufficiently to cause ischemia-mediated EAA release. Increased levels of glutamate and aspartate have been reported after global or focal brain ischemia (Benveniste, 1984; Globus, 1988; Graham et al., 1990a). Dyn 1-13 and Dyn 3-13 caused marked decreases in spinal cord blood flow after intrathecal administration; changes produced by Dyn 1-13 and Dyn 3-13 are comparable and not modified by opioid receptor antagonists, indicating that this effect is not mediated by opioid receptors (Long et al., 1987). It is also possible that dynorphin may affect release of EAA through a presynaptic mechanism. Presynaptic modulation of EAA release by NMDA receptors has been suggested from studies using cell culture or hippocampal slice techniques (McBean and Roberts, 1981; Crawford and Rosenberg, 1989; Lobner and Lipton, 1989; Morimoto and Koshland, 1990). NMDA antagonists inhibit posttraumatic release of EAA in hippocampus, possibly through a presynaptic mechanism (Panter and Faden, 1990). Dynorphin administration also causes phospholipid hydrolysis (Bakshi et al., 1990), which may cause a decline in free intracellular magnesium $\left(\mathrm{Mg}^{2+}\right)$ (Vink et al., 1990). $\mathrm{Mg}^{2+}$ has been shown to decrease after both brain and spinal cord trauma (Vink et al., 1988, 1989), with the onset of the decline temporarily correlated with EAA release (Faden et al., 1989). Recent evidence indicates that intracellular $\mathrm{Mg}^{2+}$ can produce a voltage-dependent block of NMDA channels (Johnson and Asher, 1990). Dynorphin-induced release of EAA may, therefore, also involve such a mechanism.

\section{References}

Bakshi R, Faden AI (1990a) Blockade of the glycine modulatory site of NMDA receptors modified dynorphin-induced behavioral effects. Neurosci Lett 110:113-117.

Bakshi R, Faden AI (1990b) Competitive and non-competitive NMDA antagonists limit dynorphin A-induced rat hindlimb paralysis. Brain Res 507:1-5.

Bakshi R, Newman AH, Faden AI (1990) Dynorphin A-(1-17) induces alterations in free fatty acids, excitatory amino acids, and motor function through an opiate receptor mediated mechanism. J Neurosci 10: 3793-3800.

Benavides J, Rivy JP, Carter C, Scatton B (1988) Differential modulation of $\left[{ }^{3} \mathrm{H}\right] \mathrm{TCP}$ binding to the NMDA receptor by L-glutamate and glycine. Eur J Pharmacol 149:67-72.

Benveniste HD (1984) Elevation of the extracellular concentrations of glutamate and aspartate in rat hippocampus during transient cerebral ischemia monitored by microdialysis. J Neurochem 43:13691374.

Caudle RM, Isaac L (1988) A novel interaction between dynorphin (1-13) and an $N$-methyl-D-aspartate site. Brain Res 443:329-332.

Choi DW, Viseskul V (1988) Opioids and non-opioid enantiomers selectively attenuate $N$-methyl-D-aspartate neurotoxicity on cortical neurons. Eur J Pharmacol 155:27-35.

Choi DW, Rose K, Weiss JH, Faden AI (1989) Dynorphin attenuates NMDA receptor-mediated cortical neuronal injury in vitro. Soc Neurosci Abstr 15:1113.

Cortez SC, McIntosh TK, Noble LJ (1989) Experimental fluid percussion brain injury: vascular disruption and neuronal and glial alterations. Brain Res 482:271-282.

Crawford D, Rosenberg PA (1989) A positive feedback loop generating extracellular glutamate in cortical cultures exposed to glutamine. Soc Neurosci Abstr 15:480.

Demediuk P, Daly MP, Faden AI (1989) Effect of impact trauma on neurotransmitter and non-neurotransmitter amino acids in rat spinal cord. J Neurochem 52:1529-1536.

Faden AI (1990) Opioid and non-opioid mechanisms may contribute to dynorphin's pathophysiologic actions in spinal cord injury. Ann Neurol 27:67-74.

Faden AI, Jacobs TP (1984) Dynorphin-related peptides cause motor dysfunction in the rat through a non-opiate action. $\mathrm{Br} \mathrm{J}$ Pharmacol 81:271-276.

Faden AI, Simon RP (1988) A potential role for excitotoxins in the pathophysiology of spinal cord injury. Ann Neurol 23:623-626.

Faden AI, Molineaux CJ, Rosenberger JC, Jacobs TP, Cox BM (1985) Endogenous opioid immunoreactivity in rat spinal cord following traumatic injury. Ann Neurol 17:386-390.

Faden AI, Demediuk P, Panter S, Vink R (1989) The role of excitatory amino acids and NMDA receptors in traumatic brain injury. Science 244:798-800.

Faden AI, Ellison JA, Noble LJ (1990) Effects of competitive and noncompetitive NMDA receptor antagonists in spinal cord injury. Eur J Pharmacol 175:165-174.

Globus MY (1988) Effect of ischemia on the in vivo release of striatal dopamine, glutamate, and $\alpha$-aminobutyric acid studied by intracerebral microdialysis. J Neurochem 51:1455-1464.

Gomez-Pinilla F, Tram H, Cotman CW, Nieto-Sampedro M (1989) Neuroprotective effect of MK-801 and U-50488H after contusive spinal cord injury. Exp Neurol 104:118-124.

Graham SH, Kazuya S, Panter SS, Simon RP, Faden AI (1990a) Changes in extracellular amino acid neurotransmitters produced by focal cerebral ischemia. Neurosci Lett 110:124-130.

Graham SH, Shimizu H, Newman A, Weinstein P, Faden AI (1990b) Opioid receptor antagonist nalmefene stereospecifically inhibits glutamate release during global cerebral ischemia. Soc Neurosci Abstr 16:935.

Greenamyre JT, Young AB, Penney JB (1984) Quantitative autoradiographic distribution of $\mathrm{L}-\left[{ }^{3} \mathrm{H}\right]$ glutamate-binding sites in rat central nervous system. J Neurosci 4:2133-2144.

Hagberg H, Andersson P, Kjellmer I, Thiringer K, Thordstein M (1987) Extracellular overflow of glutamate, aspartate, GABA and taurine in the cortex and basal ganglia of fetal lambs during hypoxia-ischemia. Neurosci Lett 78:311-317.

Hayes RL, Jenkins LW, Lyeth BG, Balster RL, Robinson SE, Clifton GL, Stubbins JF, Young HF (1988) Pretreatment with phencyclidine, an $N$-methyl-D-aspartate antagonist, attenuates long-term behavioral deficits in the rat produced by traumatic brain injury. $J$ Neurotrauma 5:259-274.

Herman BH, Goldstein A (1985) Antinociception and paralysis induced by intrathecal dynorphin A. J Pharmacol Exp Ther 232:2732. 
Johnson JW, Asher P (1990) Voltage-dependent block by intracellular $\mathrm{Mg}^{2+}$ of $N$-methyl-D-aspartate-activated channels. Biophys J 57:10851090.

Katayama Y, Cheung MK, Alves A, Becker DP (1989) Ion fluxes and cell swelling in experimental traumatic brain injury: the role of excitatory amino acids. In: Intracranial pressure VII (Hoff JT, Betz AL, eds), pp 584-588. Berlin: Springer.

Kendrick KM (1989) Use of microdialysis in neuroendocrinology. In: Neuroendocrine peptide methodology, pp 229-252. New York: Academic.

Lobner D, Lipton P (1989) Non-competitive NMDA antagonists and sigma-opiate ligands block glutamate release from the rat hippocampal slice during ischemia. Soc Neurosci Abstr 15:358.

Long JB, Kinney RC, Malcolm DS, Graeber GM, Holaday JW (1987) Intrathecal dynorphin $A_{1-13}$ and dynorphin $A_{3.13}$ reduce rat spinal cord blood flow by non-opioid mechanisms. Brain Res 436:374-379.

Long JB, Petras JM, Mobley WC, Holaday JW (1988) Neurologic dysfunction following intrathecal injection of Dyn A-(1-13) in the rat. II. Non-opioid mechanisms mediate loss of motor function, sensory and autonomic function. J Pharmacol Exp Ther 246:1167-1174.

Long JB, Rigamonti DD, Martinez-Arizala A, Holaday JW (1989) Non-competitive $N$-methyl-D-aspartic acid receptor inhibitors prevent persistent dynorphin A-induced hindlimb paralysis in rats. J Neurotrauma 6:59-60.

Massardier D, Hunt PF (1989) A direct non-opiate interaction of dynorphin (1-13) with the $N$-methyl-D-aspartate (NMDA) receptor. Eur J Pharmacol 170:125-126.

McBean GJ, Roberts PJ (1981) Glutamate-preferring receptors regulate the release of D-aspartate H-3 from rat hippocampal slices. Nature 291:593-594.

McIntosh TK, Head VA, Faden AI (1987) Alterations in regional concentrations of endogenous opioids following traumatic brain injury in the cat. Brain Res 425:225-233.

McIntosh TK, Romhanyi R, Yamakami I, Faden AI (1988) Exacerbation of traumatic brain injury following central administration of kappa-opiate receptor agonists. Soc Neurosci Abstr 14:1152.

McIntosh TK, Vink R, Soares H, Hayes R, Simon R (1989) Effects of $N$-methyl-D-aspartate receptor blocker MK-801 on neurologic function after experimental brain injury. J Neurotrauma 6:247-259.

Morimoto BH, Koshland DE (1990) Excitatory amino-acid uptake and $N$-methyl-D-aspartate mediated secretion in a neural cell-line. Proc Natl Acad Sci USA 87:3518-3521.

Neumaier JF, Mailheau S, Chavkin C (1988) Opioid receptor-mediated responses in the dentate gyrus and CA1 region of the rat hippocampus. J Pharmacol Exp Ther 244:564-570.

Nilsson P, Hillered L, Ponten U, Ungerstedt U (1990) Changes in cortical extracellular levels of energy-related metabolites and amino acids following concussive brain injury in rats. J Cereb Blood Flow Metab 10:631-637.

Panter SS, Faden AI (1990) Pretreatment with NMDA antagonists limits release of excitatory amino acids following traumatic brain injury. Soc Neurosci Abstr 16:1340.

Panter SS, Yum SW, Faden AI (1990) Alterations in extracellular amino acids after traumatic spinal cord injury. Ann Neurol 27:9699.

Przewlocki R, Shearman GT, Hertz A (1983) Mixed opioid/nonopioid effects of dynorphin and dynorphin related peptides after their intrathecal injection in rats. Neuropeptides 3:233-240.

Shapira Y, Yadid G, Cotev A, Niska A, Shohami E (1990) Protective effect of MK 801 in experimental brain injury. J Neurotrauma 7:131139.

Snell LD, Morter RS, Johnson KM (1988) Structural requirements for activation of glycine receptor that modulates the $N$-methyl-Daspartate operated ion channel. Eur J Pharmacol 156:105-110.

Stevens CW, Yaksh TL (1986) Dynoprhin A and related peptides administered intrathecally in the rat: a search for putative kappa opiate receptor activity. J Pharmacol Exp Ther 238:833-838.

Terrian DM, Johnston D, Claiborne BJ, Ansah-Yiadom R, Strittmatter WJ, Rea MA (1988) Glutamate and dynorphin release from a subcellular fraction enriched in hippocampal mossy fiber synaptosomes. Brain Res Bull 21:343-351.

Thomson AM (1989) Glycine modulation of the NMDA receptor. Trends Neurosci 12:349-353.

Trujillo KA, Akil H (1991) Inhibition of morphine tolerance and dependence by the NMDA receptor antagonist MK-801. Science 251: 85-87.

Vink R, McIntosh TK, Demediuk P, Weiner MW, Faden AI (1988) Decline in intracellular free magnesium concentration is associated with irreversible tissue injury following brain trauma. J Biol Chem 263:757-761.

Vink R, Yum SW, Lemke M, Demediuk P, Faden AI (1989) Traumatic spinal cord injury in rabbits decreases intracellular free magnesium concentration as measured by ${ }^{31} \mathrm{P}$ magnetic resonance spectroscopy. Brain Res 490:144-147.

Vink R, McIntosh TK, Faden AI (1990) $\mathrm{Mg}^{2+}$ in neurotrauma: its role and therapeutic implications. In: $\mathrm{Mg}^{2+}$ and excitable membranes (Strata P, Carbone E, eds), pp 125-145. Berlin: Springer.

Walker JM, Moises HC, Coy DH, Baldrighi G, Akil H (1982) Nonopiate effects of dynorphin and des-Tyr-dynorphin. Science 218:11361138.

Watson EJ, Khachaturian H, Coy D, Taylor L, Akil H (1982) Dynorphin is located throughout the CNS and is often co-localized with alpha-neoendorphin. Life Sci 31:1773-1776. 